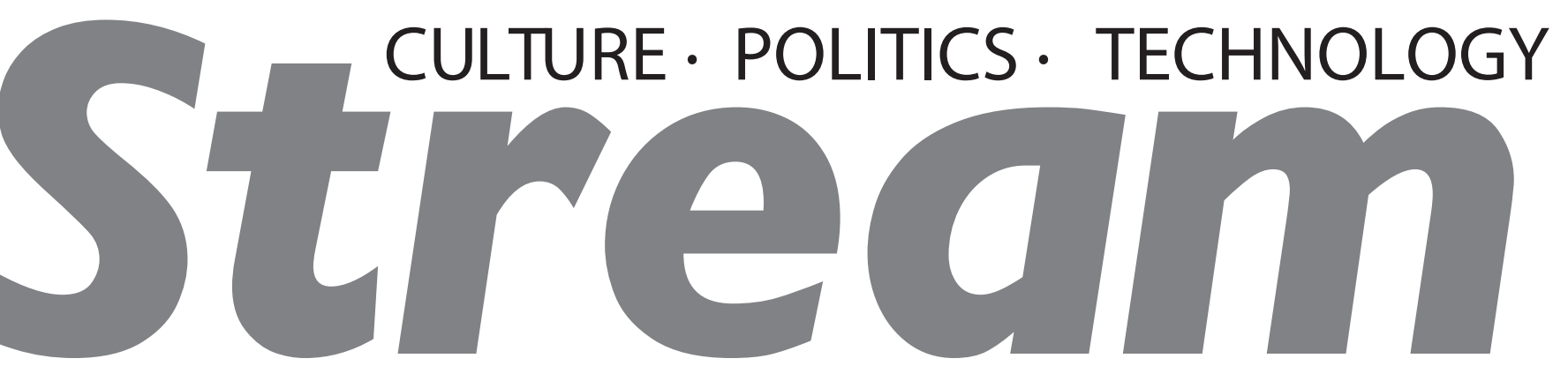

A Graduate Journal of Communication • Summer 2011 • 4(1) • ISSN 1916-5897 • www.streamjournal.org

Stream: Culture/Politics/Technology is a peer-reviewed, open-access e-journal published by the Communcation Graduate Student Caucus at Simon Fraser University.

Managing Editor: Arselan Butt

Editorial Board: Arsalan Butt, Rob McMahon, Marcos Moldes, Bojin Traykov, Danielle Deveau, Heather Morrison

Copy Editors: Danielle Deveau, Casey McCarthy, Carolyn Liu, Julia Aoki

Design: Laurynas Navidauskas Layout: Bob Neubauer

This journal provides a unique, national forum for emerging Canadian researchers. Encompassing communication studies approaches to the often overlapping "streams" of culture, politics and technology, Stream challenges conceptions of these subjects with innovative, interdisciplinary scholarship.

Visit www.streamjournal.org for more information.

The editors would like to thank and acknowledge the work of all those who volunteered as peer-reviewers.

\section{Submit to Stream}

Stream is interested in publishing articles and book reviews by Canadian graduate students in communication studies and related fields. Papers should fit into one of the three proposed "streams," but we invite contributors to challenge their conceptions of these subjects with interdisciplinary approaches to these subject areas. We hope that this student initiative will become a space for graduate students to publish new work and expand upon new ideas, contributing to a thriving graduate intellectual culture.

Visit www.streamjournal.org for full author guidelines and register to submit a paper.

\section{Stream and Creative Commons}

Stream supports and strives to integrate the ideals of the creative commons and copyleft movements at every possible level. To that end, journal articles are immediately freely available to the public, released under a Creative Commons Attribution-Noncommercial-No derivative works licence.

Furthermore, they may be reproduced and distributed freely for noncommercial uses if the author is identified and nothing is changed.

Consider including Stream articles in your students’ courseware packages.

\title{
Become a Peer-reviewer
}

Register at www.streamjournal.org and enter yourself into our database of graduate student reviewers.
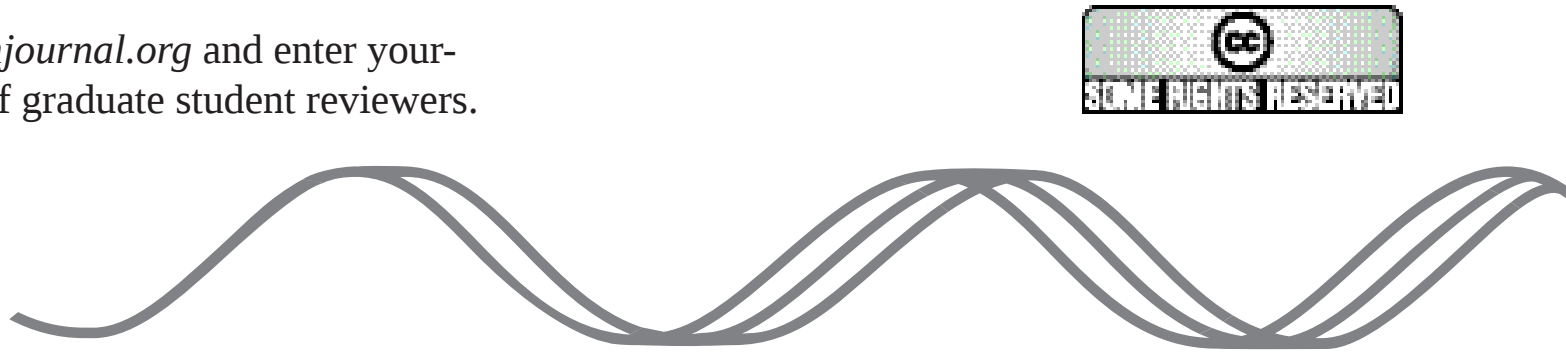


\title{
Global and Local Media Dynamics in Identity Con- struction Among British Muslims After September I I
}

\author{
Mohamed Ben Moussa
}

\section{Introduction}

The September 11 terrorist attacks were one of the most mediated events in history. They targeted the heart of a major Western megalopolis that is a global economic, cultural, and media centre. Images of destruction, shock, and suffering were displayed on TV screens and newspapers' front pages for a very long time. It was a major media spectacle in modern history that "unfolded in a city that was one of the most media-saturated in the world and that played out a deadly drama live on television" (Kellner, 2004, p. 43).One of the major consequences of this media coverage is that it brought Muslims and Islam to the fore in western societies. Akbar (2001) aptly maintains that "the terrible and tragic events of September 11 have opened a Pandora's box of questions about Islam."

In Britain, for instance, many issues such as religious fundamentalism, terrorism, and the status of multiculturalism in society have gained unprecedented attention in the media after these attacks.

Mercer (cited in Hall, 1992, p. 275) argues that "identity only becomes an issue when it is in crisis." Indeed, as the media and popular attention to Muslims and Islam-related issues increased dramatically, Muslim diasporas in the West have found themselves under immense pressures to defend their culture, faith and identity while proving their loyalty to their host countries. This experience has been only heightened and inflated by the global flows of ideas, images, and discourses made possible by transnational media such as satellite channels, which certainly affect how Muslim diasporas interpret their everyday life, their experience as well as their status in society. This situation begs three main questions: How can we better conceptualize and understand the notion of Muslim Identity? To what extent media coverage of 9/11 has affected Muslim diasporas' identity building? And, finally, what implications satellite television channels have for Muslims' identification process?

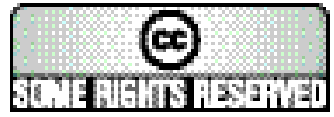

(C) 2010 Mohamed Ben Moussa

Some rights reserved. This work is licensed under a Creative Commons Attribution-Noncommercial-No Derivative Works 2.5 Canada Licence. Visit creativecommons.org or streamjournal.org for more information. 


\section{British Muslims}

\section{A Brief Historical Background}

Although Muslims started to settle down in Britain as early as in 1860s, large-scale immigration to the country was the "result of post- Second World War reconstruction and the eventual long boom, coinciding with the decolonization of the British Empire” (Poynting \& Mason, 2007, p. 3). The notions of 'Muslim community' and 'Muslim identity' are, however, relatively recent ones as they emerged distinctively only in the late 1980s and early 1990s. Before that, Muslims were usually perceived within ethnic categories in as much as "ethnic identifications [...] rather than religion were recognised in society as the key signifiers of individual and collective difference" (Ansari, 2003, p. 9). This explains why demographic statics on British Muslims became available only in 2001 after a question on religion was added to the 2001 census in the United Kingdom (Abbas, 2004, p. 27). Moreover, although dominant discourses paint British Muslims as a largely homogeneous community, Muslim communities in the country come from diverse ethnic origins and historical backgrounds that have shaped their experiences as minority groups. This diversity is bound to affect the way different Muslim groups interpret, practice and link religion to their daily life (Mandeville, 2001; 2003).

\section{Emergence of Muslim Identity}

Most commentators agree that the emergence of a 'Muslim' community proclaiming a shared identity dates back to the early 1980s due to various events such as the rise of populist English nationalism and the New Right

1. In 1988, Salman Rushdie, a British citizen of Indian origin, published Satanic Verses, a novel that caused much controversy in many Islamic countries and the Muslim community in the UK because it was perceived to contain irreverent depiction of Prophet Mohammed. The controversy led Imam Khomeini, Iran's leader at the time, to call for the killing of Rushdie. As a result, Rushdie was forced to live under police protection for several years. movement, the Rushdie affair, ${ }^{1}$ and, later on, the 1991 Gulf war. But the notion of 'Muslim identity' has been generally opposed from the start by the White majority and the media (Richardson, 2002). Muslim identity has been perceived as a threat to the existing system because it was perceived as a "politicised religious identity" (Modood, 2000, p. 51) that contradicts British traditional values (Poole, 2002). In fact, compared with other ethnic minorities in Britain, Muslims have been considered as an "alien minority, with social and cultural values and beliefs systems diametrically opposed to those of the west” (Khan, 2000, p. 31). While this perception feeds on contemporary experience of Muslims in Britain as immigrants and an 'alien' minority, it is also rooted in a long history of rivalries and colonization in the relation between the Islamic world and the Christian West (Said, 1978; 1997). As Abbas (2004, p. 29) points out, "just as present-day Islamophobia relies on history to fill in the substance of its stereotypes, the contemporary fear of Muslims has its own idiosyncratic features connecting it with the more recent experi- 
ences of colonialism, decolonization, immigration, and racism”.

\section{Media and Public Perception of British Muslims}

Numerous research studies have found that the representation of Muslims in mainstream media is predominantly a negative one (Richardson, 2002; Whitaker, 2002). A research study that surveyed the British newspapers between 1993 and 1997, for instance, found that these newspapers predominantly ignored covering British Muslims' life and culture, and that when they did, the coverage was predominantly negative (Richardson, 2002, p. 228). Richardson (p. 226), thus, concludes that Muslims are excluded, first, from "the position of 'Britishness' they are perceived to lack; and second, Muslims are excluded from the position of 'Britishness' by virtue of the 'Islamicness' that they are perceived to have.” The Runnymede trust ${ }^{2}$ committee report (1997) concluded that Islamophobia was a rampant phenomenon in the UK society and associated it with the spread of xenophobia. The report summarized anti-Muslim discourse in society and in the media into eight points:

1. Islam seen as a single monolithic bloc, static and unresponsive to new realities.

2. Islam seen as separate and other - (a) not having any aims or values in common with other cultures (b) not affected by them (c) not influencing them.

3. Islam seen as inferior to the West - barbaric, irrational, primitive, sexist.

4. Islam seen as violent, aggressive, threatening, supportive of terrorism, engaged in 'a clash of civilisations'.

5. Islam seen as a political ideology, used for political or military advantage.

6. Criticisms made by Islam of 'the West' rejected out of hand.

7. Hostility towards Islam used to justify discriminatory practices towards Muslims and exclusion of Muslims from mainstream society.

8. Anti-Muslim hostility accepted as natural and 'normal' (1997, p. 2).

The negative attitude towards Islam and Muslims in British society is not limited to the symbolic field but extends to other forms of social and economic discriminations. According to a report by the European Monitoring Centre 
on Racism and Xenophobia (EUMC) on employment in Britain, for instance, Pakistanis and Bangladeshis, who constitute the majority of the Muslim community in the country, "had unemployment rates higher than 20\%, compared to only $6 \%$ in the broader population” (Cesari, 2009, p. 9)

\section{British Muslim Experience After 9/11}

If negative perception and representation of Muslims were widespread prior to September 11 terrorist attacks, the latter events constituted a landmark in the experience of Muslim minority in Britain as well as in the rest of the Western world. The EUMC reported that attacks against Muslims in the United Kingdom after 9/11 saw a significant rise as "incidents of violent assault, verbal abuse and attacks on property were noted, some of which were very serious" (Allen \& Nielson, 2002, p. 29). Numerous studies have demonstrated that mainstream media's coverage of Muslims-related issues shot up dramatically in the aftermaths and the years that followed the attacks. One study concluded that both broadsheet and tabloid newspapers use overtly emotional description of Muslims and Islam, although tabloid newspapers more frequently associated the religion and its followers with terrorism (Baker, 2010). Baker notes that "British perceptions of Islam have been inextricably linked to terrorism since September 11th, 2001, with the tabloids providing a more emotionally visceral response” (p. 327). While Poynting and Mason (2007) also note an intensification of media and popular vilification of Muslims after $9 / 11$, they conclude that this treatment constitutes only a continuation of pre-September situation: "the much-clichéd 'Day that Changed the World' in September 2001 did not actually see the world reinvented anew” (p. 16) as far as British Muslims' experience is concerned. The scale and intensity of the backlash against Muslims prompted Abbas (2004) to claim that Muslims in Britain feel that "part of the reason for their continued existence as an unaccepted and often despised minority is based on the presence of the 'evil demon': the media” (p. 27). To what extent, therefore, does the representation of diasporic Muslims by the media, especially after September 11, affect their identification process and the way they perceive their status as a minority in society? 


\section{Understanding Identity}

\section{Identity as a Discourse}

Before considering answering the last question, it is important first to discuss the process of identity construction, both as an individual and a collective experience, and its link to media consumption. It is commonly assumed that identity is an innate and static characteristic of the self. Yet, as Giddens (1991) asserts, "self-identity is not a distinctive trait or even a collection of traits, possessed by the individual. It is the self as reflexively understood by the person in terms of her or his biography” (p. 53). Self-reflexivity is the outcome of the narratives people construct about themselves, and, thus, it is discursively constructed. Because people are always producing meanings and constructing discourses through language and out of their experiences, their identities are, thus, never complete or static, but constantly in flow and in the process of becoming. As argued by Stuart Hall (1996):

Identities are about questions of using the resources of history, language, and culture in the process of becoming rather than being: not 'who we are' or 'where we came from', so much as what we become, how we have been represented and how that bears on how we represent ourselves (p. 4).

Yet, identity is neither wholly fluid nor open to endless reconstructions. It is a process "comprising both constraints and freedoms" (Melluci, 1997, p. 65). This is because "we can alter it, but only within the constraints imposed by our inherited constitution" (Parekh, 2000, p. 5). Furthermore, identity is continually being produced within the "vectors of a similarity and difference" (Barker, 1999, p. 28). But while differentiation allows for the production of culture and meaning, it can also be "a site of danger, of negative feelings, of splitting, hostility and aggression towards the 'Other"” (Hall, 1997, p. 238).

\section{Mass Media and Identity Construction}

Media play a central role in the formation of communities by creating an imagined unity among people and a sense of belonging to a community among them (Anderson, 1991). This role has become even more pervasive in late-modern society where communication and media are not only connecting people but are also at the heart of economic and knowledge production, thus permeating every level of our private and public experiences. While the media do not totally supplant our direct experience with the social and objective world, their importance cannot be exaggerated if we state that "the information, images and ideas made available by the media may for most people, be the main source of an awareness of a shared past time (history) and of a present social location” (McQuail, 2000, p. 64). This is even more critical in 
the case of diasporic communities where media, particularly transnational media, connect them to their countries of origin and act as a nexus where past memories and life are constantly actualized and channelled into the present and local experience, thus serving as main channels through which the negotiation and reproduction of identity are enacted (Christiansen, 2004; Gillespie, 2002; Karim, 2003).

\section{The Role of Transnational Media: The Case of Satellite Channels}

A key characteristic of diasporic life is the sense of division between and belonging to two or more countries, 'homes,' cultures and existential situations that reflect their dislocation, and their continual search for identity and fixation. Indeed, "at the heart of the notion of diaspora is the image of a journey [...] paradoxically about settling down, about putting roots elsewhere” (Brah, 1996, p. 182). By allowing instantaneous and quasi permanent interconnectedness across geographical borders and barriers, the diffusion of diverse types of transnational media such as satellite television in the last two decades has exacerbated the sense of deterritorialization and experience of journey among diasporas. Indeed, the transnational linkages and flows of images and information allowed by these new media can empower diasporic communities both to resist assimilation into mainstream cultures of host countries and, at the same time, construct alternative and hybrid identities. However, according to Gillespie (2006), these media can also entrench these communities into "world-imagining and world-making activities that cocoon them in ideological ghettos, preventing exposure to competing or alternative discourses and representations of social, political and cultural life” (p. 907).

Diasporas living in the West have always been among the earliest and most savvy users of transnational media, from the smaller-scale media, such as the fax machines, to mass media such as the internet and satellite television. According to Karim (1998), for instance, diasporas were "among the earliest adopters of DBS [direct broadcast satellite] for cross-border transmissions with its pizza-sized receiving dish installed on homes becoming the symbol of community self-assertion" (p. 1). This is only normal given their "hunger for news” (Gillespie, 2006, p. 913) and desire to remain constantly connected to their homelands. As far as Muslim Arab diasporas are concerned, numerous studies have shown that they rely heavily on transnational news channels like Al-Jazeera as their main source of news (Karim, 2003; El-Nawawy \& Iskandar, 2002; Miles, 2005; Lynch, 2006). These channels have contributed to the establishment and reinforcement of transnational Arab and Muslim public spheres where millions of audiences from the Arab world and diaspora can 
simultaneously watch and participate in the same TV programs. Paradoxically, however, the popularity of these channels among diasporic communities can lead also to increasing fragmentation of national news audiences in the host countries (Gillespie, 2006; Karim, 2003). Thus, while the intersection between national and transnational public spheres in the daily life of migrant communities can generate spaces of dialogues between competing discourses and identities, it can also create divisions and tension, particularly during times of crisis as it is the case with September 11.

\section{The Role of Community Institutions in the Production of Identity}

Despite their pervasive presence, mass media "do not monopolise the flow of information we receive, nor do they intervene in all our wider social relations” (McQuail 2002, p. 65). In fact, diasporas' consumption of and interaction with mass media are always performed in parallel and conjunction with diverse interpersonal and mediated forms of communication, and their interpretation is usually "carried out in everyday conversations in the home, in cafes, at work with friends and family 'here' and 'there"” (Gillespie, 2006, p. 906). While Dayan (1998) maintains that it might be unproductive to limit the concept of diasporic media to conventional media such as the radio, television and print media since it is necessary to focus on "the various practices, institutions and organisations [...] that link the different segments of diasporic ensembles each other" (p. 181). As far as diasporic Muslims are concerned, various commentators have noted the central role ethnic and religious institutions play as social and communication networks that compete with and in some cases supplant the role played by mass media. According to Rawan (2001), a mosque is among "the most important pillars of traditional and interpersonal communication throughout traditional Islamic society” (p. 179). While in her study on Muslim communities in Chicago, Schmidt (2004) found that Muslim institutions and community organisations are "the focal points for community activity,” (p. 10) and play a central role in reinforcing identity bonds among migrant Muslim communities, and act as networks of communication between them. This raises an important question on how these alternative forms of communication intersect with and influence the act of media use and consumption among British Muslims.

\section{Conceptual Framework}

The current study draws on Castells' (2004) interpretation of identity, particularly his distinction between three forms and origins of identity building, namely, "legitimizing identity," "resistance identity," and "project identity." Legitimizing identity is "introduced by dominant institutions of society to extend and rationalize their domination vis-à-vis social actors” (Castells, 2004, 
p. 8); resistance identities are those generated by "actors who are in positions/conditions devalued and/or stigmatized by the logic of domination, thus building trenches of resistance and survival on the basis of principles different from or opposed to those permeating the institutions of society" (Castells, 2004, p. 8). As for project identities, they are generated by social actors "on the basis of whatever cultural materials are available to them, [to] build a new identity that redefines their position in society and, by so doing, seek the transformation of overall social structure” (p. 8). Castells’ paradigm resists any attempt to attach identity to fixed core features while it links identification to power relation interaction between social actors. As Castells argues, "from the point of view of social theory, no identity can be an essence, and no identity has, per se, progressive or regressive value outside its historical context" (p. 8). Concurring with Castells, Cerulo (1997) affirms that "the social constructionist approach to identity rejects any category that sets forward essential or core features as the unique property of a collective's members" (p.387).

\section{Methodology}

This study relies on qualitative analysis of in-depth interviews conducted with members of the Muslim community in the city of Leeds, UK. In-depth interviewing is appropriate for the type of issues in which the researcher has to dig under the surface of social and cultural manifestations to discover "what is usually hidden from ordinary view or reflection or to penetrate to more reflective understandings about the nature of that experience" (Johnson, 2002, p. 107).

Accordingly, fifteen first-generation Arab Muslims were interviewed, the majority of whom were located and approached in the city's biggest mosque, since it is a major community centre for Muslim community. The choice of first generation participants stems from the fact that, unlike South Asian Muslims who came to the country after WWII, Arab diaspora is a more recent one and constitute mainly of first generation immigrants. The respondents are aged between 37 to 65 years and have all been living in Britain for periods of 10 to 25 years. Though the interviews covered the same issues, they were semi-structured, for the questions were neither structured nor worded in an identical way. This gave informants a great deal of freedom to engage in a conversation-like form of speaking, and allowed the adaptation of questions to the different informants who come from diverse backgrounds. The interviews took 60 to 90 minutes, were tape-recorded and conducted in diverse locations in the city of Leeds in the UK. The researcher informed the partici- 
pants about the objective of the interviews and they all provided their consent on taping the interviews and publishing the transcripts.

To code and analyze the data, a qualitative method was employed, namely open coding. According to this method, "events/actions/interactions are compared with others for similarities and differences. They are also given conceptual labels. In this way, conceptually similar events/actions/interactions are grouped together to form categories and subcategories” (Corbin \& Strauss, 1990, p. 12).

\section{Analysis and Discussion}

\section{The Dynamics of Media Consumption among British Arab Muslims}

3. To protect the privacy of participants, only their pseudonyms are used in the current study.
As it is the case with most of the British people who 'spend, on average, 25 hours per week watching television’ (Livingstone, 1996, p. 305), television, more than any other medium, plays an important role in the life of diasporic Muslims, in terms of both the time spent watching it and its importance in the life of diasporic Muslims in general. Indeed, all informants confirmed that television holds a central position at home since watching it is the main activity they perform with their families when they gather in evenings or on weekends. They all indicated that the advent of transnational channels transformed their viewing habits and the way they interact with media in general. Raed, ${ }^{3}$ a British Iraqi and self-employed engineer, said the following about his media use prior to the advance of satellite television:

We used to watch only BBC TV channels. There was a scarcity in news. We got news about the Arab World by listening to Arab radio stations on short waves, [which] did not have a good reputation, except the Arabic service in the BBC World service. We used to stay late in the night to listen to this channel.

Thanks to the revolution in communications technologies, Arab satellite channels using Direct Broadcast Satellite (DBS) and, later on, digital technologies mushroomed after the second Gulf war in 1991 (Ayish, 2001; Sakr, 2001). This provided a plethora of channels to Arab Muslims living in Britain, the most popular of which is the famous news network Al-Jazeera. While the informants displayed a wide range of program preferences, they all agreed on the fact that news programs interest them most. As Yones, a British Moroccan and civil servant, points out:

I follow the news at every hour. [We watch] mainly Arab channels. I don't mind watching English ones, but they cover events like [those of] Palestine only briefly. Arab channels transmit the conflict in live and a vivid way [...]you see events before your eyes. Sometimes, I watch English ones, but you can't cover events in five minutes. 
4. These two channels mainly broadcast religious programs.
For Muslim Arab audiences, news about Arab and Islamic countries holds priority in their daily media consumption habits. However, diasporic Arab Muslims do not constitute a homogeneous audience or media consumers, in general. The data generated by the informants' testimonies shows that there is a wide spectrum of diversity at the level of media choices and television consumption habits. At the far end of the spectrum, some respondents indicated that they hardly watched local channels because the latter broadcast programs that contain sexual content that they found too licentious and against their religious and moral convictions. Speaking about his preferences, Hisham, a British Iraqi teacher, points out:

At home we watch only Arab channels. [...]. We watch mainly news programs on AlJazeera, and religious programs on Al-Manar and Eqra'a channels. ${ }^{4}$ We don't watch English channels. Their channels are immoral. They show immoral things even in ads to promote goods. It is acceptable for them, but not for us. I fear about our children, and so we don't switch to [these channels].

Hisham's case illustrates clearly the role of satellite channels in isolating some diaspora members from the rest of society, especially in terms of sharing national news and mediated public spheres. It also reflects the dialectic between the private and public spheres in the experience of diasporas. In fact, the house plays a central role in the life of diasporic communities because it often becomes a substitute and proxy for the home country. The reproduction of the home land takes place through various practices and objects such as furniture and decoration, food, organization, and sharing of space, use of language, and gender relationship, among many others. While watching satellite channels contribute to this process of "home" reproduction, local channels' programs can create tension by infringing on acceptable "decent” behaviour. Zokaie and Philips (2000) note that the "interaction between western values and Islamic values is often seen [by British Muslims] as potentially disruptive and as something which requires constant vigilance by the parents to keep their children in control” (p. 49). It is worth noting how Hicham frames the issue through "our" vs. "their" channels, illustrating how media consumption and choices play an active role in the reinforcement of "othering" and production of identity. Refusal to watch "their" channel becomes an act of resistance against cultural assimilation and at the same time a tool of selfessentialization and reification of identity.

At the other end of the spectrum, another informant declared that he watched Arab channels only for a very short time each day. Because he is married to a British woman of Pakistani origin, and his children have grown up in Britain, Raed says:

I am the only person at home who knows Arabic very well, and I don't want to impose my choices on the other members of the family [...] so normally I contend by 
watching only one news hour on Al-Jazeera. The remaining time we watch English channels...

Raed's case is that of multilingual and multiethnic households where media consumption and preferences are characterized by negotiations and compromises between family members. This process is further complicated by the fact that the parents are linked to separate "home" countries, which is bound to shape TV watching habits and experiences. Negotiating and finding compromises on sharing TV experiences quickly become lifelong habits and part of diasporic communities' everyday endeavours to reconstruct their life out of articulations between different temporal, geographic, psychological, and hermeneutic processes and experiences.

Some informants declared that, though they prefer to watch Arab channels, they also like to watch local ones because the latter provide them with programs that most benefit them in their daily life. Thus, Anas, a Moroccan restaurant-owner, indicated that he followed regularly Ramsey's Kitchen Nightmares' program on Channel 4 because he learns from it how to enhance the profile of his restaurant. Accordingly, though they are widely watched and in most cases preferred over other media outlets, transnational channels do supplant local media and the role of the latter in the daily life of diasporic Muslims. Muslim Arab diaspora members are enmeshed in multilevel relationships and networks at the local level, and therefore consumption of British media is part of their everyday life and participation in their communities.

While members of Muslim Arab diasporas may share certain media consumption habits, they differ in how they interpret and deal with media content itself. In fact, though the majority of respondents expressed a preference for Arabic Satellite news channels such as Al-Jazeera, many of them indicated that they do not blindly trust these channels. Hisham, for instance, stated that he does not trust all that Arab channels say about Iraq. According to him, Arab channels sometimes,

Practice propaganda and look for sensationalism when they report news about bombings in Baghdad [...]. They seek to attract audiences and I don't like it. I call my relatives there and they are not even aware of these bombings.

Likewise, commenting on the way she interprets both local and transnational media, Rajaa, a British Egyptian medical consultant, says:

When I want to know about something, I check the Guardian, the BBC and, of course, Al-Jazeera. But I trust Al-Jazeera more. I think they give complementary view... but when I read in the Guardian about Palestine I can't help reading it critically and see how they present news, but when I see Al-Jazeera, it's not the same.

Alicia Horton 
Spot available at http:// www.axe.ca/main. html\#en-section-player.
It’s not a thing I do consciously, but when I think of it now, I realize it. I cannot help analysing why [English media] say this or that.

The latter testimonies reflect how mass media cannot monopolise truth in an age where audiences can always check the veracity of news through alternative communication technologies, such as the telephone and the Internet, and by comparing one media outlet to another. They also reveal how audience members are active readers of media texts, and that they can become producers of news, using mediated and non-mediated forms of communication to check, recreate, and communicate information, commentary, and interpretations to neighbours, relatives, and friends. The notion of the active audience should not be limited to the sense of "resistant" readers who are able to counter-interpret media messages. As Livingstone (1998) argues, the notion of resistance depends "not so much on the interpretative process but on the relation between the textual and extra-textual resources drawn upon during making sense of television” (p. 189).

\section{Identity Formation among British Muslims}

Maxim Rodinson (Said, 1997, p. 57-58) distinguished between three levels of reference to Islam: the first level is the teachings contained in the sacred texts, mainly the Qur'an; the second consists of the various and conflicting interpretations of these texts; the third, refers to the way in which various ideologies have been lived and put to practice. Said even adds a fourth level, that of the connotations the term "Islam" evokes when used or referred to in the West. These four layers of reference inform and shape in a verity of ways how Arab Muslims perceive their identity and experience in Britain.

While the small sample of respondents used to generate the data for the current study cannot be claimed to be representative of Arab Muslim diaspora in Britain, they yielded, nonetheless, some interesting correlations between respondents' media consumption habits and the way they perceive their own identity. Those respondents who watch exclusively Arab transnational channels are the ones who emphasised most of their affiliations to their country of origin and religion over any other types of belonging. Commenting on what it means to him to be a Muslim living in Britain for the last 20 years, Rashid argues:

I'm a Muslim, I'm an Iraqi, too [...] Iraq was the place where I grew up [...] but I feel I'm more of a Muslim than an Iraqi. Islam sets us a clear path to follow. It protects us from being totally dissolved within the British society.

First generation immigrants such as Arab Muslims diaspora maintain in general strong ties with their home countries, and these links have been further 
reinforced by transnational media. In the words of Karim (2003), "homeland politics form a major topic for the media of some diasporas, especially those consisting largely of first-generation migrants” (p. 3). But as Rashid indicates, this form of affiliation competes with religious identity that may sometimes take precedence over the first one. The sense of identification with a Muslim community, both at the local and global levels, rather than with an ethnic group or country of origin is the outcome of a slow process of deterritorialization and a transformation Muslim diaspora members go through in the process of rebuilding new lives in their new home country.

Other informants affirmed they viewed the Muslim identity as categorically opposed to the British one on moral grounds. Arguing about the dangers of living within a different cultural and social context compared to the one of his native country, Said, a British self-employed Algerian, points out:

It'd be better if you want to keep your identity and origins not to integrate too much with [the British], because you will then lose your religion [...]. They believe in individual freedom. A man from us cannot do whatever he likes except according to the precepts of God.

Said's last statement, on the one hand, reflects a clear essentialist perception of identity since it reduces the "Muslim" identity to a few moral guidelines and religious precepts, while it views the "English" identity as diametrically opposed to and uncompromisingly different from the "Muslim" one. On the other hand, self-essentialization is a common discursive product of "diaspora consciousness [that] lives loss and hope as a defining tension” (Clifford, 1994, p. 312). Highlighting one's difference from the other is a defensive reaction against territorial up-rootedness and an expression of defiance in the face of negative perception of Muslim communities in society.

However, not all informants stated that religion is their primary source of identification. Anas, a British Moroccan accountant, for instance, asserted that though he is a Muslim, he feels his identity as a Moroccan and Maghrebian takes precedence over other sources of identification:

I'm Moroccan first. Moroccan culture is deeply rooted in me. When I meet other Muslims I feel they look at me first as a Moroccan. It's in their subconscious, and mine. My first adherence is to Morocco.

Indeed, despite the importance of religion, it is far from being the sole variable shaping British Muslim identity because ethnic, national, regional and class variables may strongly compete with religious identity and sometimes eclipse it. Besides, the boundaries of identity are never clearly marked neither complete as they are constantly redefined. Commenting on how his experience in diaspora enabled him to rediscover his affiliation to a Pan-Arab cultural background, Anas says: 
When I came to Britain, I had a different perception of Arabs from the Middle East and the Gulf [...] I felt I had no connection with them. I didn't even want to know them. I used to go out with the Spanish, the French, and the Italians. I felt closer to them. It is only later that I realized that I also shared many other things with them [Arabs from the Middle East].

Anas's experience reveals how being a Muslim is not something innately defined in all its contours prior to individual experience; it is a mixture of cultural heritage, collective experience and individual personality and biography. It also shows how diasporic experience is a constant search for stability and fixation, which is typical of diasporic communities who are "constantly producing themselves anew, through transformation and difference" (Hall, 1993, p. 402). While Anas' journey led him to rediscover new connections and sources of identification, Rajaa, on the other hand, affirms that being a Muslim does not necessarily entail that she can equally identify with all members of British Muslim communities. Describing how she perceives nonArab Muslims, mainly South-Asian women, Rajaa points out:

When I see a Pakistani woman, I think she is a Muslim woman. I don't think I share with her many cultural aspects, though her religion is same as mine. There is something that unites us, but it's different when I think of somebody from Iraq, or Saudi

Arabia. I feel closer to them.

Thus, respondents' narratives above sheds light on the heterogeneity characterizing the way British Muslims, particularly first generation Arab immigrants, perceive their identity. The terms "Muslims" and a "Muslim identity" are generic ones that encompass multiple and interrelated forms of affiliations, as well as modes of living and interpretations of religion that inform how British Muslims identify themselves as individuals and members of Muslim communities at the local and global levels. A similar complexity also characterizes British Muslims' interaction with and consumption of both local and transnational media. Moreover, while the data confirmed the centrality of transnational media in the life of British Arab Muslims and their role in identity formation among this community, it also illustrated that the impact of transnational media is not uniform, and does not necessarily increase the isolation of Muslim diasporas. In fact, British Muslims' interaction with media and their identity discourses are characterized by important variations, as the discussions above have demonstrated. Paradoxically, however, such heterogeneity is contrasted by a quasi-homogeneous perception among Muslim diaspora of the negative role British media play in representing them as a community. 


\section{Media Role and Identity Construction among British Muslims after 9/11}

As mentioned earlier, though media representation of the 'Muslim identity' in Britain has always been predominantly negative, the intensity of such perception significantly augments during time of crises and major events at the national and international levels. In correlation with this attention, Muslim diasporic communities' consciousness about their religious identity acquires prominence over all other forms of affiliations. As Ansari (2003) points out, Islam becomes "the main or even the sole identity for many [British] Muslims, particularly when they have been criticised or attacked by others on the basis of their religion” (p. 4-5).

Most respondents agreed on the fact that the events of September 11 marked a turning point in the history of Muslims around the world, in general, and those living in Western countries, in particular. One of the respondents said that he was physically attacked in the market, while another was verbally abused in the street shortly after 9/11. Most of them, however, indicated that their main concern in the aftermath of the attacks was to avoid being spotted out as Muslims in the street. Yones, for example, says:

I tried to change so as not to appear as a Muslim. Before, I let my beard grow sometimes and I wore the traditional Moroccan dress [...] I used to walk in the city centre and people came and asked me about the dress. After 9/11 I started to fear to go out with my wife as she wears the Hijab. We feared reaction from people who do not know Islam.

Most informants who have been living in Britain for more than 20 years, however, asserted that though the representation of Muslims by the British media deteriorated after September 11, it had already become noticeably negative after the Rushdie affair. According to them, the current situation is a continuation of the past treatment of Muslims by the British media. Azzam, a retired British Libyan, for instance, notes:

Certainly things nose-dived in the last 3 or 4 years and the media have exploited the events of September 11 to stigmatise Muslims. [But] it started with the Rushdie affair, which cast a very black shadow on Muslims' image [...]. It is as if it happened again and again.

If the Rushdie affair and the second Gulf war propelled for the first time British Muslim diaspora to the front of the scene, the events of September 11 further set them in the centre of media attention and public's concern. While the coverage of Muslims-related issues by the British media has increased dramatically after that date, the concern of Muslims over being constantly 
5. Abu Hamza al-Masri is a radical religious cleric known for his provocative interpretation of Islam and incitation to use violence. He is serving a seven year term in prison in the UK and is facing extradition to the US on terrorism charges. Tabloid newspapers often run extensive coverage of his actions and declarations, turning him into a symbol of "bad" Islam in Britain. singled out has equally increased. Thus, all informants expressed that, though the fear of being physically targeted in public places lasted only a few months after the events, the concern over being profiled as Muslims and associated with terrorism has persisted.

All informants expressed their concern about the British media's covering of news and issues about Muslims in a way that associates between Islam as a religion and terrorism. Indeed, some informants expressed doubts about the practices of some media for their constant coverage of radical Islamic figures, Said, for instance, states that:

[The media] don't care about making people know Islam, but to stigmatise it. [You] see how they make interviews with Abu- Hamza Al-Masri. ${ }^{5}$ It's a waste of time. It benefits neither Muslims nor the British.

Said's statement was confirmed by the EUMC's report on the backlash against Muslims in the UK after 9/11 that stated that a "range of voices could be heard in the [British] media although a disproportionate amount of coverage was devoted to extremist Muslim groups and British Muslims who declared their willingness to join an Islamic war against the West” (Allen \& Nielson, 2002, p. 29). Thus, Raed asserts that the current war on terrorism has created a favourable atmosphere for hostile discourse against Islam to develop in recent years:

September 11 was a golden opportunity for all those who wanted to harm Islam. Before, if they wanted to talk about it endlessly, a lot of people will be tired of it. Now, the constant mentioning of terrorism makes people keen at understanding more about those who threaten their life.

Though Raed believes there are important ethnic and cultural variations between Muslim communities, for him Muslims are unified not in what they are but in the way they are represented and perceived as the other:

It doesn't matter [for the British] really if you were an Arab, a Hindu, or an African. It is enough that you are different and that you are in an inferior position, and that's the end of it. The relationship that binds you is that between an aboriginal citizen and an alien.

The possibility for Muslim diasporas to compare both British and Arab transnational media coverage of the war on terrorism, increases Muslims' mistrust of British media's intentions and overall performance. Comparing the British media coverage of the September 11 terrorist attacks and their coverage of the events in Palestine and Iraq, Yones says:

The world knew about September 11 because it was covered around the clock. You watched buildings falling, people dying, people crying. They made interviews with people who lost their loved ones. For that reason people were affected. In Palestine 
or Iraq they don't talk to those who lost their relatives [...], even when Al-Jazeera or Al-Arabia show pictures, they say the pictures are fake.

One direct impact of transnational media such as satellite television is that they have created more fusion between national and supra-national public spheres, which is shaping not only how diasporas experience long distance events, but also how they interpret domestic politics and local media representation discourses. Moreover, although some informants declared that they are not practicing Muslims, they indicated that they can identify with British Muslims on the ground that they were all viewed by the ethnic majority and media as being identical. In the words of Rajaa:

I see there is a world of differences between us [...]. When I read newspapers, I feel closer to my people, I feel the differences, I feel they don't understand us, and I see that, for them, we will always remain these inferior people with problems, just causing problems.

In fact, as discussed earlier, the notion of 'Muslim identity' engulfs many forms of affiliation and interpretations of religion, which permit secular and non-practicing members of the community to consider themselves as Muslims. Thus, despite being a non-practicing Muslim, Rajaa's feeling of bitterness about the way Muslims are perceived is clearly worded in a discourse that sets up clear boundaries between "us" (Muslims), and "they" (the media and white majority, as a whole). The last observation here has been confirmed by Robbins and Aksoy's study (2005) that found that identification with Muslim community intensified dramatically among the largely secular Turkish diaspora in London. Thus, Rajaa’s testimony illustrates how identity is socially and discursively constructed through dominant power relations in society. Rather than being contingent on predefined sets of doctrinal believes and cultural components, her identity narrative is informed by an oppositional discourse that seeks to challenge and resist dominant representations of Muslims.

\section{The Role of Alternative Communication: Community Centres as an Example}

Mass media, both local and transnational forms, undoubtedly, play an influential and dynamic role in the way British Muslims construct their identity; yet, these media do not monopolise this role, neither do they determine how these people understand their lives and experiences. Various commentators have highlighted the role of ethnic media, such as newspapers, local radio stations, and TV stations in the life of diasporic communities (Karim, 1998; Husband, 2005; Alia and Bull, 2005). In comparison, the role of community spaces and institutions has received little attention. In fact, a number of respondents declared they were members of such institutions where they share 
with other Muslims their experiences, organise common activities, or perform religious and cultural ceremonies. The mosque, however, remains the most important among all these forms of organised communal life. Unlike in many Islamic countries where the majority of mosques are used mainly for prayer, in Britain, mosques act as cultural and social centres that provide many services such as language learning, social help, and moral guidance for local communities, among other services. Commenting on the role of the Mosque for him as a Muslim, Raed notes:

For me, [the mosque] was the place that helped me to bear the feeling of estrangement, and where to meet other [Muslim] people. The mosque organises activities during religious feasts and vacations. In addition, it is where we pray daily and can meet each other. When I came here, I did not know many things, and I met people [in the mosque] who guided me.

Most respondents also noted that the role of the mosque has been enhanced by the religious freedom enjoyed by Muslims in Britain. Contrary to many Islamic countries, mosques in Britain remain open all day, and not only at prayer times. Moreover, British Muslims can organise various activities in the mosque that enable them to rediscover their religion and question it, as well. Anas, for instance, claimed that he was not a practicing Muslim when he first came to Britain, but that he rediscovered many new things about Islamic culture and religion that attracted him to the religion:

In the mosque here, you have on Monday a religious sermon by Sheikh Judea. Tuesday, you can have a lecture, the next day another activity $[\ldots]$ you see $[\ldots]$ you sit with an Imam [...] who allows you to ask any question in your mind and he encourages you to think and gives you freedom [...] this doesn't exist at home. They used to teach us only ablutions and inheritance.

Religious identity for diasporic Muslims, thus, is not necessarily something they bring with them from their home countries and remain static. As they discover new ways to define religion itself, they start to contest "what it means to be a Muslim, what Islam means and how it should be constructed and reproduced both in the West and in the rest of the world" (Werbner, 2000, p. 315). While dominant discourse on the Muslim identity describe it as closed, parochial, and anachronistic or anti-modern, Anas' description of his journey that led him to rediscover religion shows that this type of identity can be, paradoxically, closely associated with and can be contingent upon freedom of choice and opinion, tolerance, and a modernist vision of religion as a driving force towards progress and development. 


\section{A Glimpse of Hope: Towards a Project Identity?}

Even if the data generated by informants reflects a predominantly bleak account of how Muslims are represented in the British mainstream media, some informants, nonetheless, pointed out many positive points that mark their experience as media consumers and citizens in the country. Anas, for instance, confirmed that

Channels 4 and 5 for instance show some programs that give a fair image on Muslims. But the English [audience] may retain one good image only to be destroyed in another program. They need to give more balanced programs.

Moreover, while some respondents may feel bitter towards the way British media represent or exclude them, they indicated that this does not rule out positive interaction with the rest of society. Because of the unprecedented media attention Muslims got after September 11, some people started to show more interest in Muslims and their religion as Rashid, for instance, points out:

The media may not be showing reality about us. Some people might have negative impressions about Muslims. But when I invite some [colleagues] to my house, they see our hospitality, our life at home with our families. It changes the images they have in mind.

Equally important, the majority of respondents indicated that British Muslims themselves share a considerable part of responsibility about the way the media represent them. As Azzam notes:

We are giving a negative image about ourselves. We are giving them the chance to do it. The media are double edged and we can use them also for our advantage. You see younger generations who speak beautiful English, and attend TV programmes and discuss in full confidence and authority.

Azzam's comparison between the performance of the first and second generations of diasporic Muslims reflects a belief in the importance of human action, interpersonal communication, and interaction to resist dominant discourses on Muslims. Underlying his statement is a belief in human agency and the capacity of individuals and communities to change or at least affect the course of their life and experience.

\section{Conclusions}

The study has addressed the role of media, both local and translocal in shaping identity construction among first generation Arab Muslim diaspora in Britain. It has highlighted the multiplicity characterizing the notion of "Mus- 
lim identity" that is marked by diverse and contrasting identification dynamics, from reification of identity and the self, on the one hand, to non-fixity, fluidity and constant transformation, on the other. The paper also demonstrated how media in general play a vital role, both as agents of inclusion and exclusion, in the way British Muslims construct their identity. In fact, Arab transnational media contribute significantly to reinforcing Arab Muslims' sense of belonging to and connectedness with their countries of origin and with the global Muslim community. At the same time, transnational media act as a background against which local media are interpreted, and a discursive and ideological context through which daily experiences and perceptions are filtered.

More importantly, while the study has pointed out the complexity of Muslims' experience and identification process in Britain, it demonstrated that the key unifying component in the Muslim identity is the feeling of victimhood and narrative of defiance vis-à-vis dominant representations and perceptions. Drawing on Castells' identity model, it is possible to interpret the Muslim identity in Britain as a "resistance" one against the dominant or "project identity" of Britishness from which Muslims are excluded. The Muslim identity remains mainly a reactive one, since it rises to prominence and overrides other forms of identification during times of crisis when discrimination against Muslims in the media and the public sphere become highly visible. The continuing global war on terrorism, and overwhelming Western media and public sensitivity towards and prejudice against Islam and Muslims in general means that the notion of the Muslim identity in Britain will continue to be formulated and enacted more as a resistance against the "other" than as a reflection of homogeneous cultural features.

As many respondents' testimonies suggest, there are always spaces of mediated and unmediated communication that open possibilities for interaction in society between project and resistance identities. It is true that these encounters are always underpinned by power relations, but they are nonetheless necessary venues through which project or hybrid identities can be produced. Indeed, Castells' third category of project identities can be understood as a form of hybridity, where hybrid identities are born out of power relations and contestation. Bhabha (1996) argues that "the hybrid strategy or discourse opens up a space of negotiation where power is unequal but its articulation may be equivocal" (p. 58). 
1. Other funding programs and applications from the AFA exist for emerging artists, individual artists, professional development, and independent projects among others. These programs are not discussed here.

\section{Author}

Dr. Mohamed Ben Moussa has recently received a PhD in Communication Studies from Concordia University, Montreal, Canada. He also holds an MA in Communication Studies from The University of Leeds, UK. His research interests include Information and communication technologies (ICTs) and social movements, political communication, international and intercultural communication, and media and development, among others. He can be contacted at mbenmousa@gmail.com

\section{References}

Abbas, T. (2004). After 9/11: British South Asian Muslims, Islamophobia, multiculturalism, and the state. American Journal of Islamic Social Sciences, 21(3), 26-38.

Akbar, A. (2001). Veiled truth. The Guardian Unlimited. Retrieved from http://www.guardian.co.uk/g2/story/0,3604,578239,00.html.

Alia, V., \& Bull, S. (2005). Media and ethnic minorities. Edinburgh: Edinburgh University Press.

Allen, C., \& Nielson, J. (2002). Summary report on Islamophobia in the EU after 11 September 2001. European monitoring centre on racism and xenophobia. Retrieved from http://www.fra.europa.eu/fraWebsite/attachments/Synthesis-report_en.pdf.

Anderson, B. (1991). Imagined communities: Reflections on the origin and spread of nationalism. London: Verso.

Ansari, H. (2003). The "infidel” within: The history of Muslims in Britain, 1800 to the present. London: C Hurst.

Appadurai, A. (1996). Modernity at large: Cultural dimensions of globalization. Minneapolis: University of Minnesota Press.

Aysh, M. (2001). The changing face of Arab communications: Media survival in the information age. In K. Hafez (Ed.), Mass media, politics and society in the Middle East, Cresskil (pp. 111-136). New Jersey: Hampton Press.

Baker, P. (2010). Representations of Islam in British broadsheet and tabloid newspapers: 1999-2005. Journal of Language and Politics, 9(2), 310338.

Barker, C. (1997). Global television: An introduction. Oxford: Blackwell Publishers. 
2. Introduced in 1980, the NEP strove to keep the oil-patch in Canadian hands and to prevent foreign firms from making obscene profits on booming oil prices. Its chosen weapons included a combination of subsidies, regulated prices and heavy taxes that had the effect of keeping domestic oil and natural gas prices as much as $30 \%$ below world price levels. This took about $\$ 50$ billion out of Alberta's economy in five years, sent major oil companies to the US and elsewhere, and precipitated a recession in the oil-patch (Nikiforuk, Pratt \& Wanagas, 1987).
Barker, C. (1999). Television, globalisation and cultural identities. Buckingham \& Philadelphia: Open University Press.

Bhabha, H. (1996). Culture's in-between. In S. Hall \& P. du Gay (Eds.), Questions of cultural identity (pp. 53-60). London: Sage.

Brah, A. (1996) Cartographies of diaspora: Contesting identities. London, New York: Routledge.

Castells, M. (2004). The power of identity. Malden, Malden, Mass.: Blackwell Pub.

Cerulo, K. (1997). Identity construction: New issues, new directions. Annual Review of Sociology, 23, 385-409.

Cesari, J. (2009). The securitisation of Islam in Europe. The changing landscape of European liberty and security, Research paper No 15. Retrieved from http://aei.pitt.edu/10763/01/1826.pdf.

Christiansen, C. (2004). News media consumption among immigrants in Europe: The relevance of diaspora. Ethnicities, 4(2), 185-207.

Clifford, J. (1994). Diasporas. Cultural Anthropology, 9, 302-38.

Corbin, J., \& Strauss, A. L. (1990). Grounded theory research: Procedures, canons, and evaluative criteria. Qualitative Sociology, 13(1), 3-21.

Dayan, D. (1998). Particularistic media and diasporic communications. In T. Liebes \& J. Curran (Eds.), Media, ritual and identity (pp. 103-113). London: Routledge.

El- Nawawy, M., \& Iskandar, A. (2002). Al-Jazeera: How the free Arab news network scooped the world and changed the Middle East. Boulder, Colo.; Oxford: Westview.

Giddens, A. (1991). Modernity and self-identity: Self and society in the late modern age. Cambridge: Polity Press.

Gillespie, M. (2006). Transnational television audiences after September 11. Journal of Ethnic and Migration Studies, 32(6), 903-921.

Gillespie, M. (2002). Dynamics of diasporas: South Asian media and transnational cultural politics. In G. Stald \& T. Tufte (Eds.), Global encounters: Media and cultural transformations (pp. 151-173). Luton: University of Luton Press. 
3. After ongoing erosion of its budget, the Department of Culture was, in 1987, renamed the Department of Culture and Multiculturalism. The ministry underwent significant budget and staff cuts and the mandate of the department also shifted. It now included "a new emphasis on the "cultural industries" and on the economic importance of the arts including a new language of "cultural goods and services” (Whitson, Wall, \& Cardinal, 2006).
Hall, S. (1992). The question of cultural identity. In S. Hall, D. Held \& T. Mc Crew (Eds.), Modernity and its futures (pp. 273-320). Cambridge: Polity Press in association with the Open University.

Hall, S. (1993). Cultural identity and diaspora. In P. Williams and L. Chrisman (Eds.) Colonial discourse and postcolonial theory: A reader (pp. 392-403). New York: Columbia University Press.

Hall, S. (1996). Introduction: Who needs "identity"? In S. Hall \& P. d. Gay (Eds.), Questions of cultural identity (pp. 1-17). London: Sage.

Hall, S. (1997). The spectacle of the "other.” In S. Hall (Ed.), Representation: Cultural representations and signifying practices (pp. 223-290). London: Sage.

Husband, C. (2005). Minority ethnic media as communities of practice: Professionalism and identity politics in interaction. Journal of Ethnic and Migration Studies, 31(3), 461-479.

Johnson, J. (2002). In-depth interviewing. In J. Gubrium \& J. Holstein (Eds.), Handbook of interview research: Context and method (pp.103-122). Thousands Oaks, Ca..: Sage Publications.

Karim, K. (1998). From ethnic media to global media: Transnational communication networks among diaspora communities. Retrieved from http:// www.transcomm.ox.ac.uk/working\%20papers/karim.pdf

Karim, K. (2003). Islamic peril: Media and global violence. Montreal, New York, London: Black Rose Books.

Kellner, D. (2004). 9/11, Spectacles of terror and media manipulation: A critique of Jihadist and Bush media politics. Critical Discourse Studies, 1(1), 41-64.

Khan, Z. (2000). Muslim presence in Europe: The British dimension- Identity, integration and community activism. Current Sociology, 48(4), 29-43.

Livingston, S. (1998). Making sense of television: The psychology of audience interpretation. London: Rutledge.

Livingstone, S. (1996). Audience reception. In J. Curran \& M. Gurevitch (Eds.), Mass media and society (pp. 9-28). London: Edward Arnold.

Lynch, M. (2006). Voices of the new Arab public. Columbia University Press: New York. 
Mandeville, P. (2001). Transnational Muslim politics. London, New York: Rutledge.

Mandeville, P. (2003). Communication and diasporic Islam: A virtual Ummah? In K. Karim (Ed.), The Media of Diaspora (pp. 135-147). London $\&$ New York: Rutledge.

McQuail, D. (2000). McQuail's mass communication theory. London, Thousand oaks, New Delhi: Sage Publications.

Melucci, A. (1997). Identity and difference in a globalized world. In P. Werbner \& T. Modood (Eds.), Debating cultural hybridity: Multi-cultural identities and the politics of anti-racism (pp. 58-69). London: Zed Books.

Miles, H. (2005). Al-Jazeera: The inside story of the Arab news channel that is challenging the West. New York: Grove Press.

Modood, T. (2000). La place des Musulmans dans le multiculturalisme Laïc en Grande-Bretagne. Social Compass, 47(1), 41-55.

Parekh, B. (2000). Rethinking multiculturalism: Cultural diversity and political theory. Basingstoke: Macmillan.

Poynting, S., \& Mason, V. (2007). The resistible rise of Islamophobia antiMuslim racism in the UK and Australia before 11 September 2001. Journal of Sociology, 43(1), 61-86.

Rawan, S. (2001). Interaction between traditional communication and modern: Implications for social change in Iran \& Pakistan. In K. Hafez (Ed.), Mass media, politics, and society in the Middle East (pp. 175-212). Cresskill, N.J.: Hampton Press.

Richrdson, J. (2002). British Muslims in the broadsheet press: A challenge to cultural hegemony? Journalism Studies, 2(2), 221-242.

Robins, K., \& Aksoy, A. (2005) Whoever looks always finds: Transnational viewing and knowledge-experience. In J. K. Chalaby (Ed.), Transnational television worldwide: Towards a new media order (pp. 14-42). New York: Palgrave Macmillan.

Said, E. (1978). Orientalism. New York: Pantheon Books.

Said, E. (1997). Covering Islam. London, Sydney, Auckland: Vintage.

Sakr, N. (2001). Satellite realms: Transnational television, globalization \& 
the Middle East. London, New York: I.B. Tauris Publishers.

Schmidt, G. (2004). Islam in urban America: Sunni Muslims in Chicago. Philadelphia: Temple University Press.

The Runnymede Trust Committee Report (1997). Islamophobia: Challenge for us all- A summary. Retrieved from http://www.runnymedetrust.org/ uplo ads/publications/pdfs/islamophobia.pdf.

Werbner, P. (2000). Divided loyalties, empowered citizenship? Muslims in Britain. Citizenship Studies, 4(3), 307-324.

Whitaker, B. (2002). Islam and the British press after September 11. Conference paper on Islam and the media, Central London Mosque .Retrieved from http://www.al-bab.com/media/articles/bw020620.htm.

Zokaie, S., \& Philips, D. (2000). Altruism and intergenerational relations among Muslims in Britain. Current Sociology, 48(4), 45-58. 